less happened during the Kainozoic era, and Dr. Chalmers Mitchell's observations on the condition of the volcanic hills of the Bayuda will probably indicate a more precise date.

J. W. Gregory.

\section{THE NATIONAL RESEARCH COUNCIL OF THE UNITED STATES.}

$A \mathrm{~N}$ account has recently been published of the $A$ organisation established by the National Research Council of the United States for the carrying out of its work. Americans are proud of their organising ability, and it is very interesting to study the efforts of the men of science of America to develop their scheme of mobilising the whole strength of American science for the promotion of the national well-being and for the advance of science itself.

The National Research Council was established to deal with war problems. It was started by the men of science themselves; they recognised that although the Government had already strong scientific bureaux, there were many other workers who in the isolation of their own laboratories were almost unavailable, but eager for opportunity to help. This organisation is now being completed and put on a permanent basis. We are told that it differs from organisations for similar purposes in England, Canada, Australia, and Japan in that, while recognised by Government, it was not initiated or organised by Government, and is not supported by it. Its support is derived from funds contributed by private sources.

The machinery is somewhat elaborate. There are seven divisions devoted to special branches of science and technology. These divisions are physical science, engineering, chemistry and chemical technology, geology and geography, medical science, biology and agriculture, and anthropology and psychology. The members of each of these divisions include representatives of societies dealing with cognate subjects, other scientific workers, and representatives of firms. Attached to each division there are a very large number of committees to give attention to special problems. But in addition to this classification into seven divisions there are six "general relations" divisions - a Government division, a division for foreign relations, a division of States relations, a division of educational relations, a division of industrial relations, and a division of research information. The idea underlying these divisions may be seen from their constitution. For example, the educational division has a membership including representatives of all the principal university associations, the United States Bureau of Education, the Carnegie Foundation for the Advancement of Teaching, etc. The division for research information will, we are told, be a national centre of information concerning American research work and research workers, with all its information promptly available to institutions and individuals interested in knowing at any time what problems NO. 2625 , VOL. IO4] are under investigation in America and their status.

The National Research Council has permanent headquarters in Washington, with an executive staff of men of science giving their whole time to the work of their respective positions. Each of the divisions has a resident chairman and a small office staff in Washington.

It is not yet possible to say much as to the actual work of the new Council. From the list of subjects being studied by the numerous committees of the different divisions, it would appear that problems of wide national interest are receiving first attention. If we compare the American organisation with that of our own Research Department as shown in its annual reports, it would seem that in America the scientific worker is organised to a greater, and the industrial leader to a less, degree than in this country. There is nothing in the American scheme that quite coincides with the research associations for each large industry established by our Research Department. It is clear that both the American Department and our own will have much to learn by watching each other's development, and it is to be hoped that some degree of co-operation may be established in connection with problems of interest and importance to both nations.

The official organ of the National Research Council for the publication of accounts of research work and of committee and other reports will be the Proceedings of the National Academy of Sciences, but in addition the Council proposes to publish a Bulletin at irregular intervals. The first number of the Bulletin contains articles by Dr. G. E. Hale and other writers on different aspects of the national importance of scientific and industrial research. Dr. Hale gives an account of the origin of the Council and outlines its objects. He argues against the view that organised effort in science may hamper the individual investigator and hinder personal initiative. In his opinion, well-planned co-operation stimulates the individual and brings out his best and most original efforts. The Council will favour this type of co-operation, but is opposed to all attempts at a central control of research.

The Hon. Elihu Root writes on the need for organisation in research, and holds that science has been arranging, classifying, methodising; and simplifying everything except itself. One fears that the degree of organisation suggested by $\mathrm{Mr}$. Root would almost amount to the control which Dr. Hale tells us the Council has no wish to attempt. Other articles dealing with the relation of research to industry are written by men of wide experience in large industrial concerns, and the Bulletin concludes with an account by $\mathrm{Mr}$. Howe of the organisation of scientific and industrial research in the United States, the British Empire, France, Italy, Japan, and Belgium. An appendix contains a list of non-military researches undertaken by the Council covering a wide range of subjects, and especially numerous in the section of medical science. 